\title{
Особливості перебігу та лікування гострого поширеного перитоніту онкологічного генезу
}

\author{
O. I. IVASHCHUK, I. YA. HUSHUL, V. YU. BODYAKA, V. P. UNHURIAN, I. D. POSTEVKA
}

Bukovynian State Medical University

\section{PECULIARITIES OF THE CLINICAL COURSE AND TREATMENT OF ACUTE EXTENSIVE PERITONITIS OF ONCOLOGICAL GENESIS}

\begin{abstract}
У статті представлено алгоритм хірургічної тактики гострого поширеного перитоніту на тлі раку товстої кишки, розроблений на основі дослідження клінічно-лабораторних особливостей перебігу останнього. Встановлено, що гострий поширений перитоніт, який виник внаслідок ускладнення злоякісного новоутворення товстої кишки, особливо в поєднанні із частковою кишковою непрохідністю, здебільшого єзагальним, з великою кількістю (понад 600 мл) серозного перитонеального ексудату, супроводжується недостатністю двох і більше систем органів, а також внутрішньочеревною гіпертензією III-IV ступенів. Запропонований алгоритм хірургічної тактики за гострого поширеного перитоніту, на тлі раку товстої кишки, включає застосування бальної шкали вибору методу остаточного або тимчасового закриття черевної порожнини, визначення оптимального терміну виконання лапароперції. За участю 75 пацієнтів доведено ефективність даного алгоритму, а саме відмічається зниження кількості “локальних” післяопераційних ускладнень на 25,7 \% (р<0,01), “системних” - на 23,3 \% (p<0,05) та післяопераційної летальності - на 20,8 \% (p<0,05).
\end{abstract}

\begin{abstract}
Algorithm of a surgical method of acute extensive peritonitis against a background of the large intestine, elaborated on the basis of the research of clinico-laboratory peculiarities of the clinical course of the latter, is presented in the article. It has been established that acute extensive peritonitis, which arose in consequence of a malignant neoplasm complication of the large intestine, particularly in combination with bowel obstruction, being for the most part general, with great quantity (over 600 ml) of serous peritoneal exudates, is accompanied with insufficiency of two and more organs' systems, as well as intraperitoneal hypertension III-IV degrees. The proposed algorithm of the surgical procedure at acute extensive peritonitis against a background of the large intestine cancer, includes the application of a grade-scale of the method choice of the final or temporary closure of the abdominal cavity, determination of the optimal term of performing laparotomy. The efficacy of the method, namely, a decrease of the "local” postoperative complications quantity is marked $25 \%(p<0.05)$, “systemic" $23.3 \%$ (p<0.05) and postoperative mortality $-20.8 \%(p<0.05)$ was demonstrated on 75 patients.
\end{abstract}

Постановка проблеми і аналіз останніх досліджень та публікацій. Останнім часом рак товстої кишки входить до п’ятірки найпоширеніших злоякісних новоутворень, захворюваність та смертність від яких продовжують невпинно зростати [8].

Більшість пацієнтів звертається до лікувального закладу в пізніх стадіях онкологічного захворювання, яке досить часто супроводжується такими ускладненнями, як кишкова непрохідність, некроз стінки кишки, внаслідок чого виникає гострий поширений перитоніт (ГПП) із летальністю від 53,8 до 90 \% [8, 9, 11].

Така висока летальність зумовлена тим, що перитоніт виникає на тлі вже існуючих патологічних змін, спричинених раковою хворобою, які значно ускладнюють перебіг захворювання та призводять до незадовільних результатів лікування [3, 10].
Незважаючи на існуючу кількість наукових досліджень, присвячених лікуванню ГПП, більшість 3 них не враховує впливу злоякісного новоутворення на організм. Зазвичай такі пацієнти отримують загальноприйняте лікування, як при звичайному перитоніті, проте наявність злоякісної пухлини в організмі значно спотворює клінічний перебіг захворювання, утруднює своєчасну діагностику, тим самим суттєво погіршуючи результати лікування $[8,11]$.

Все це змушує шукати нові підходи щодо хірургічної тактики даного ускладнення, а саме показання до повторних санацій черевної порожнини, частоти та кількості лапароперцій (повторне розкриття черевної порожнини) тощо.

Мета роботи: розробити алгоритм тактики лікування хворих на рак товстої кишки, ускладне- 
ний ГПП, на основі виявлених клінічно-лабораторних особливостей перебігу останнього.

Матеріали і методи. Обстежено та проліковано 107 хворих на ГПП, який виник внаслідок ускладнення захворювань товстої кишки. Всі пацієнти розподілені на три групи. Першу групу утворили 32 особи із ГПП непухлинної етіології. Другу групу склав 41 хворий на рак ободової та прямої кишок у III В $\left(\mathrm{T}_{3-4} \mathrm{~N}_{1} \mathrm{M}_{0}\right)$, III C $\left(\mathrm{T}_{1-4} \mathrm{~N}_{2} \mathrm{M}_{0}\right)$ та IV $\left(\mathrm{T}_{1-4} \mathrm{~N}_{1-2} \mathrm{M}_{1}\right)$ стадіях захворювання, ускладнений ГПП.

Пацієнти першої та другої груп отримували лікування згідно із клінічними протоколами надання медичної допомоги хворим з невідкладною хірургічною патологією органів живота (наказ МО3 України № 297 від 02.04.2010 року “Про затвердження стандартів та клінічних протоколів надання медичної допомоги зі спеціальності “Xiрургія”).

Третю групу утворили 34 хворих на рак ободової та прямої кишок у III B, III C та IV стадіях захворювання, ускладнений ГПП, які отримували лікування згідно із запропонованою нами хірургічною тактикою.

Середній вік осіб першої групи становив $(53,5 \pm 2,35)$ року, другої - $(68,8 \pm 1,65)$ року, а третьої - $(63,6 \pm 1,71)$ року.

Забір периферичної венозної крові проводили перед виконанням першої санації черевної порожнини та впродовж перших 14-ти діб перебування у стаціонарі.

Об'єм ексудату черевної порожнини визначали після виконання лапаротомії шляхом аспірації останнього електровідсмоктувачем медичним “БИОМЕД” 7 А-23 В.

Поширеність перитоніту та його морфологічні прояви оцінювали за класифікацією, представленою в протоколах надання медичної допомоги хворим з невідкладною хірургічною патологією органів живота [7].

Рівень внутрішньочеревного тиску (ВЧТ) вимірювали через сечовий міхур, згідно із рекомендаціями Міжнародного товариства з вивчення синдрому абдомінальної компресії. Для оцінки ступеня внутрішньочеревної гіпертензії (ВЧГ) використовували класифікацію, згідно з якою при І ступені рівень ВЧТ становить 10-15 mmHg, при II ступені - 16-20 mmHg, при III ступені - 21$25 \mathrm{mmHg}$ та при IV ступені - понад $25 \mathrm{mmHg}$ [1].

Визначення концентрації середньомолекулярних пептидів плазми крові проводили за методом Н. И. Габриэлян [2]. Для кількісної їх оцінки використовували суму отриманих екстинцій при $\lambda=254$ та $\lambda=282$ нм. Відповідь виражали в умовних одиницях (у. од.).

Статистичну обробку отриманих результатів досліджень проведено на персональному комп'ютері 3 використанням електронних таблиць Microsoft Excel, а також програми IBM SPSS Statistics. Перевірку нормальності розподілу даних у вибірках проводили шляхом застосовування критеріїв Shapiro-Wilk. 3 метою оцінки вірогідності різниці між відсотковими частками двох вибірок використовували критерії Фішера. Для порівняльного аналізу, при нормальному розподіленні незалежних груп, застосовували критерій (t) Стьюдента. У разі ненормального розподілення неперервних перемінних використовували критерії Манна-Уїтні (U-тест). Розбіжності отриманих результатів вважали статистично вірогідними при $\mathrm{p}<0,05$, що є загальноприйнятим у медико-біологічних дослідженнях, де р - рівень значущості.

Результати досліджень та їх обговорення. Враховуючи, що на перебіг ГПП впливає низка чинників, які різняться між собою за ступенем впливу, нами розроблено бальну шкалу алгоритму хірургічної тактики щодо необхідності застосування програмованих санацій черевної порожнини (лапароперцій) та частоти їх застосування. При розробці даної шкали вибору показань щодо тимчасового або остаточного закриття черевної порожнини, терміну виконання лапароперції ступінь впливу кожного чинника оцінювали за десятибальною системою.

Однією із важливих ознак запропонованої нами бальної шкали є ступінь розповсюдження ексудату по черевній порожнини. Проведені клінічнолабораторні дослідження вказують, що у хворих на ГПП онкологічного генезу вірогідно переважає кількість осіб із загальним перитонітом [4]. Слід відмітити переважання в 1,46 раза $(\mathrm{p}<0,01)$ КСП плазми крові у пацієнтів другої групи. У першій та другій групах пацієнтів КСП плазми крові при загальному перитоніті в 1,23 раза $(\mathrm{p}<0,05)$ вища порівняно із дифузно-розповсюдженим.

Не менш важливе значення має кількість ексудату черевної порожнини, аспірованого під час попередньої санації останньої. Проведені дослідження вказують на переважання в 4,23 раза $(\mathrm{p}<0,01)$ відсотка пацієнтів першої групи (17 (53,1%) осіб) із об'ємом перитонеального ексудату до 200 мл проти другої та третьої груп (9 (12,0%) осіб). Відсутня вірогідна різниця між відсотком хворих на ГПП онкологічного та неонкологічного генезу із кількістю ексудату черевної порожнини від 200 до 400 мл. Відсоток пацієнтів другої та третьої груп 
(46 (61,3 \%) осіб) із об’ ємом перитонеального ексудату понад 600 мл переважає в 3,26 раза $(\mathrm{p}<0,01)$ відсоток хворих першої групи (6 (18,8 \%) осіб).

При вивченні морфологічних проявів ГПП слід зазначити переважання в 1,81 раза $(\mathrm{p}<0,05)$ відсотка пацієнтів (34 (45,3 \%) особи) другої та третьої груп із серозним характером перитонеального ексудату проти першої (8 (25,0%) осіб). Між відсотком хворих на ГПП онкологічного та неонкологічного генезу із серозно-фібринозним характером ексудату черевної порожнини відсутня вірогідна різниця. Відсоток пацієнтів першої групи (9 (28,1 \%) осіб) із фібринозно-гнійним характером перитонеального ексудату переважає в 1,5 раза (р>0,05) відсоток хворих другої та третьої груп (14 (18,7\%) осіб) $[4,6]$.

Спостерігається переважання в 1,59 раза $(\mathrm{p}<0,01)$ КСП плазми крові у пацієнтів другої групи порівняно з першою.

Суттєво ускладнює перебіг раку товстої кишки наявність часткової обтураційної кишкової непрохідності у поєднанні із ГПП. Отримані результати дослідження КСП плазми крові, залежно від наявності ознак часткової обтураційної кишкової непрохідності, вказують на переважання в 1,61 раза $(\mathrm{p}<0,01)$ показників другої групи порівняно з першою.

Результати дослідження КСП плазми крові, залежно від ступеня поліорганної дисфункції за шкалою SOFA, вказують на переважання в 1,26 раза $(\mathrm{p}<0,05)$ показників другої групи.
Визначення ступеня ВЧГ у передопераційному періоді має важливе прогностичне значення, оскільки рівень ВЧТ дає змогу спрогнозувати розвиток ВЧГ у ранньому післяопераційному періоді [4]. Отримані результати дослідження КСП плазми крові, залежно від ступеня ВЧГ, вказують на переважання в 1,16 раза $(\mathrm{p}<0,05)$ показників у пацієнтів другої групи.

Враховуючи вищенаведені чинники, нами розроблено шкалу їх оцінки з метою вибору тимчасового або остаточного закриття черевної порожнини при ГПП, яка представлена в таблиці 1.

Базуючись на результатах проведених досліджень стосовно вивчення особливостей клінічного перебігу, впливу локальних та загальних чинників на перебіг ГПП, який виник внаслідок ускладнення раку товстої кишки, нами розроблено алгоритм хірургічної тактики при даному захворюванні (рис. 1).

Всім хворим на ГПП, джерелом якого є ускладнення раку товстої кишки, після госпіталізації в лікувальний заклад, виконуючи передопераційну підготовку, визначали ступінь органної дисфункції за шкалою SOFA та кожні три години вимірювали рівень ВЧТ [5].

Після виконання лапаротомії, під час ревізії органів черевної порожнини, визначали ступінь тяжкості останнього за Мангеймським індексом перитоніту (МІП), аспірували перитонеальний ексудат, вимірюючи його об’єм.

Таблиця 1. Шкала вибору тимчасового закриття черевної порожнини при гострому поширеному перитоніті онкологічного генезу залежно від кількості балів (бал)

\begin{tabular}{|c|c|c|}
\hline Ознака & Критерій оцінки ознаки & Кількість балів \\
\hline \multirow{2}{*}{$\begin{array}{l}\text { Площа поширення ексудату черевної } \\
\text { порожнини }\end{array}$} & Дифузно-розлитий & 2 \\
\hline & Загальний & 6 \\
\hline \multirow[t]{3}{*}{ Кількість ексудату черевної порожнини } & До 200 мл & 3 \\
\hline & Від 200 до 400 мл & 6 \\
\hline & Понад 400 мл & 10 \\
\hline \multirow[t]{4}{*}{ Морфологічні ознаки перитоніту } & Серозний & 3 \\
\hline & Серозно-фібринозний & 5 \\
\hline & Фібринозно-гнійний & 7 \\
\hline & Каловий & 10 \\
\hline \multirow{2}{*}{$\begin{array}{l}\text { Розвиток перитоніту на тлі часткової } \\
\text { обтураційної кишкової непрохідності }\end{array}$} & Без кишкової непрохідності & 3 \\
\hline & Із кишковою непрохідністю & 10 \\
\hline \multirow[t]{3}{*}{ Ступінь органної дисфункції за шкалою SOFA } & $0-8$ & 4 \\
\hline & $9-12$ & 7 \\
\hline & 13 та більше & 10 \\
\hline \multicolumn{3}{|c|}{ У разі внутрішньочеревної гіпертензії III-IV ступенів перед виконанням операційного втручання } \\
\hline \multicolumn{2}{|c|}{ Внутрішньочеревна гіпертензія перед операцією I-II ступенів } & 0 \\
\hline \multirow{3}{*}{$\begin{array}{l}\text { Рівень внутрішньочеревного тиску при } \\
\text { зведенні країв рани під час операції }\end{array}$} & До 12 mmHg & 2 \\
\hline & Від 13 до 20 mmHg & 5 \\
\hline & Понад $20 \mathrm{mmHg}$ & 10 \\
\hline
\end{tabular}

Примітка. До 24 балів - остаточне закриття черевної порожнини; понад 24 бали - зведення країв рани ситуаційними швами. 
Після виконання операційного прийому (видалення пухлини, виведення кишкової стоми, санації та дренування черевної порожнини) пацієнтам із I ступенем тяжкості перитоніту черевну порожнину “традиційно” пошарово зашивали. Пацієнтам із II-III ступенями тяжкості перитоніту вибір методу закриття черевної порожнини визначали згідно із запропонованою бальною шкалою. До 24-х балів - черевну порожнину “традиційно” пошарово зашивали, а понад 24 бали - зводили краї рани ситуаційними швами.

Терміни виконання лапароперції визначали за допомогою шкали SOFA та ступеня ВЧГ. Так, при ступені органної дисфункції до 8 балів за шкалою SOFA та ВЧГ - I-III ступенів лапароперцію вико- нували на 2-гу добу. Це пояснюється тим, що ВЧГ призводить до швидкого розвитку поліорганної недостатності на тлі вже наявних тяжких метаболічних змін у життєво важливих органах та системах організму, які виникають внаслідок ГПП $[1,5]$.

У разі ВЧГ І ступеня та органної дисфункції за шкалою SOFA понад 8 балів виконували лапароперцію на 3-4-ту доби, оскільки існує необхідність у корекції поліорганної недостатності, а ВЧГ І ступеня не потребує декомпресії черевної порожнини операційним шляхом [1].

Під час виконання лапароперції, крім санації черевної порожнини, проводили корекцію розташування дренажів, а за допомогою запропонованої бальної шкали визначали метод закриття че-

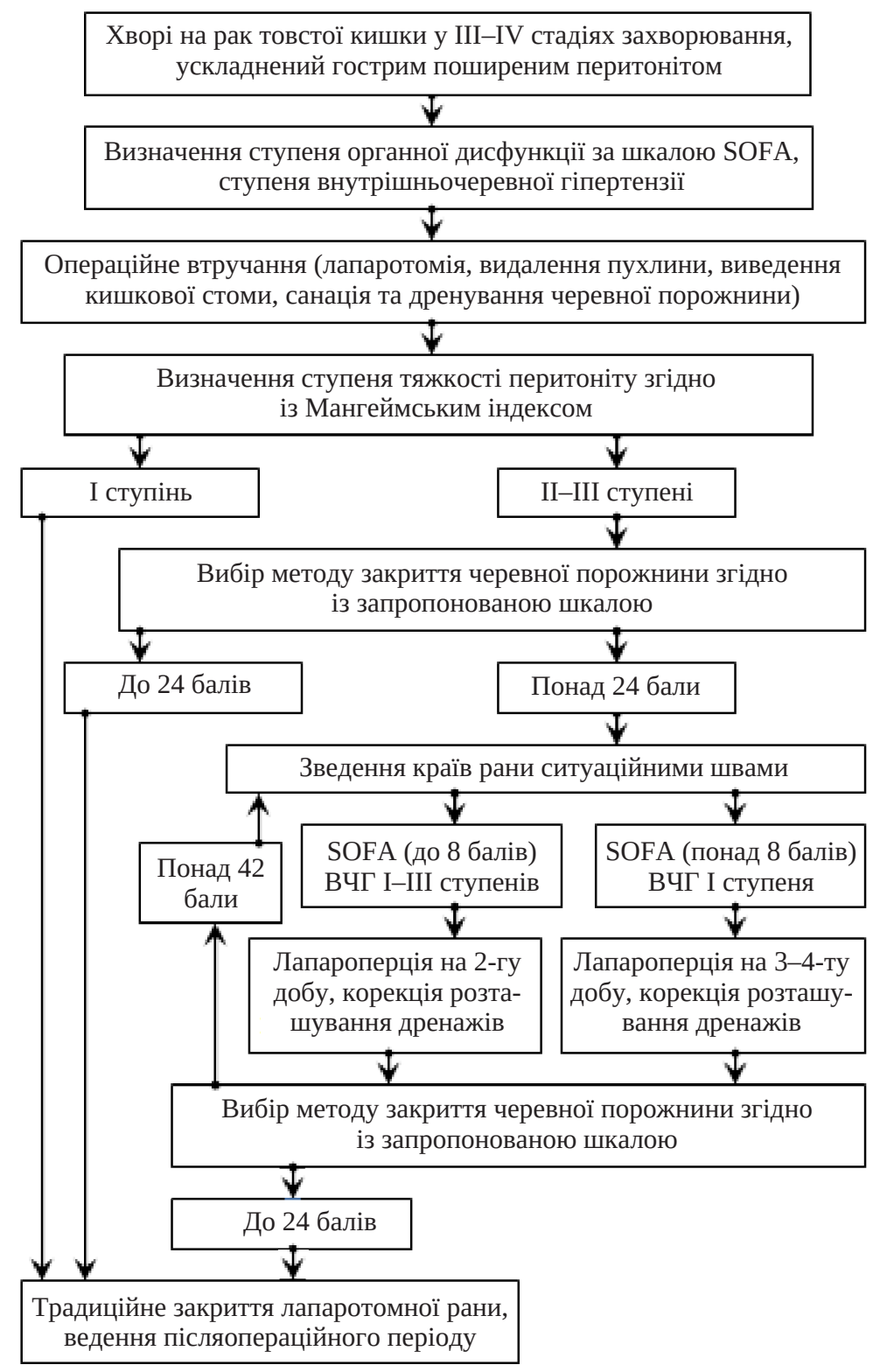

Рис. 1. Алгоритм тактики лікування гострого поширеного перитоніту, джерелом якого є ускладнення раку товстої кишки. 
ревної порожнини. До 24-х балів - черевну порожнину “традиційно” закривали, а понад 24 бали - знову зводили краї лапаротомної рани ситуаційними швами.

Аналіз ефективності запропонованого алгоритму хірургічної тактики показав, що при застосуванні останньої у хворих на ГПП онкологічного генезу післяопераційна летальність у другій групі становила 56,1 \% (23 особи із 41), а в третій - 35,3\% (12 осіб із 34), тобто знизилася на 20,8 \% $(\mathrm{p}<0,05)$.

Важливим клінічним показником ефективності застосування запропонованого алгоритму хірургічної тактики при ГПП онкологічного генезу $€$ вивчення та порівняння кількості післяопераційних ускладнень.

Для кращого аналізу післяопераційних ускладнень всі наявні випадки, залежно від їх характеру, розподілені на дві групи - “локальні” (безпосередньо пов’язані з органами черевної порожнини та їі стінками) та “системні” (серцево-судинна, дихальна або ниркова недостатність, а також їх поєднання - поліорганна).

Аналізуючи результати дослідження частоти розвитку післяопераційних ускладнень при ГПП онкологічного генезу, які представлені в таблиці 2, слід зазначити невірогідну різницю “локальних” ускладнень в їх структурі, за винятком утворення нориць та абсцесів, де кількість останніх у групі порівняння вірогідно менша. Порівнюючи частоту “локальних” післяопераційних ускладнень разом, слід відмітити на 25,7 \% (p<0,01) меншу в третій групі дослідження.

Кількість “системних” післяопераційних ускладнень у третій групі пацієнтів менша, проте ця різниця вірогідна тільки при порівнянні поліорганної недостатності. Якщо об’єднати всі “системні” післяопераційні ускладнення разом, то відмічається на 23,3 \% $(\mathrm{p}<0,05)$ менша їх кількість у третій групі пацієнтів.

Таблиця 2. Частота розвитку післяопераційних ускладнень при гострому поширеному перитоніті, який виник на тлі раку товстої кишки, абс., \%

\begin{tabular}{|c|c|c|c|}
\hline \multirow{2}{*}{\multicolumn{2}{|c|}{ Причини післяопераційних ускладнень }} & \multicolumn{2}{|c|}{ Група пацієнтів } \\
\hline & & друга & третя \\
\hline \multirow{7}{*}{ 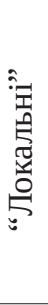 } & Рання спайкова непрохідність & $3(7,3 \%)$ & $1(2,9 \%)$ \\
\hline & Внутрішня кровотеча & $1(2,4 \%)$ & $2(5,9 \%)$ \\
\hline & Перфорація гострих виразок кишечнику & $2(4,9 \%)$ & $1(2,9 \%)$ \\
\hline & Утворення нориць та абсцесів & $6(14,6 \%)$ & $1(2,9 \%)^{*}$ \\
\hline & Нагноєння післяопераційної рани & $5(12,2 \%)$ & $2(5,9 \%)$ \\
\hline & Евентрація післяопераційної рани & $2(4,9 \%)$ & - \\
\hline & Всього: & $19(46,3 \%)$ & $7(20,6 \%) *$ \\
\hline \multirow{5}{*}{ 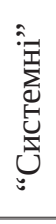 } & Дихальна недостатність & $4(9,8 \%)$ & $2(5,9 \%)$ \\
\hline & Серцево-судинна недостатність & $6(14,6 \%)$ & $4(11,8 \%)$ \\
\hline & Ниркова недостатність & $4(9,8 \%)$ & $3(8,8 \%)$ \\
\hline & Поліорганна недостатність & $10(24,4 \%)$ & $3(8,8 \%)^{*}$ \\
\hline & Всього: & $24(58,6 \%)$ & $12(35,3 \%)^{*}$ \\
\hline & Загальна кількість пацієнтів & $41(100 \%)$ & $34(100 \%)$ \\
\hline
\end{tabular}

Примітка. * - вірогідна різниця між показниками обох дослідних груп.

Таким чином, новим аспектом, який запропонований нами в лікуванні ГПП онкологічного генезу, є застосування запропонованого алгоритму хірургічної тактики, який грунтується на оптимальному виконанні програмованих лапароперцій, їх кількості.

Висновок. Впровадження запропонованого алгоритму хірургічної тактики при ГПП на тлі раку товстої кишки, який включає застосування бальної шкали вибору методу остаточного або тимчасового закриття черевної порожнини, визначення терміну виконання лапароперції знижує кількість “локальних” післяопераційних ускладнень на 25,7 \% ( $<0,01)$, “системних” - на 23,3 \% ( $<<0,05)$, післяопераційну летальність - на 20,8 \% $(\mathrm{p}<0,05)$.

\section{СПИСОК ЛІТЕРАТУРИ}

1. Бодяка В. Ю. Роль внутрішньочеревної гіпертензії в післяопераційному перебігу гострої кишкової непрохідності та гострого поширеного перитоніту : автореф. дис. на здобуття наукового ступеня доктора мед. наук : спец. 14.01.03 “Хірургія” / В. Ю. Бодяка. - Вінниця, 2014. - 46 с.

2. Габриэлян Н. И. Опыт использования показателей средних молекул в крови для диагностики нефрологических заболеваний у детей / Н. И. Габриэлян // Лаб. дело. - 1984. № 3. - С. 7-12.

3. Гресько М. М. Сучасні діагностичні критерії гострого пе- 


\section{ОРИГІНАЛЬНІ ДОСЛІДЖЕННЯ}

ритоніту / М. М. Гресько, О. В. Стасишена, С. В. Колібаба // Науковий вісник міжнародного гуманітарного університету. - 2014. - № 7. - С. 13-14.

4. Гушул I. Я. Особливості перебігу гострого поширеного перитоніту онкологічного генезу / I. Я. Гушул, О. І. Іващук, В. Ю. Бодяка // Буковинський медичний вісник. - 2015. - Т. 19, № 2 (74). - С. 62-65.

5. Диагностическая значимость мониторинга внутрибрюшного давления в выборе лечебной тактики у больных перитонитом / В. Ф. Зубрицкий, А. Л. Щелоков, А. А. Крюков [и др.] // Инфекции в хирургии. - 2007. - № 3. - С. 52-54.

6. Прогностичне значення Мангеймського індексу перитоніту в сучасній невідкладній абдомінальній хірургії / О. Б. Матвійчук, Д. М. Бешлей, Л. Я. Клецко [та ін.] // Український журнал хірургії. - 2010. - № 1. - С. 110-113.

7. Стандарти організації та професійно орієнтовані протоколи надання медичної допомоги хворим з невідкладною хірургічною патологією органів живота : науково-методичне видання / за редакцією Я. С. Березницького, П. Д. Фоміна. К. : ТОВ “Доктор-Медіа”, 2010. - 470 с. - (Серія “Бібліотека” Здоров’я України”).

8. Surgical treatment for complicated forms of colorectal cancer / A. A. Antadze, N. I. Lekvtadze, G. I. Chikobava, G. B. Gvantseladze // Georgian Med. News. - 2013. - N. 225. - P. 7-11.

9. Post-operative peritonitis due to anastomotic dehiscence after colonic resection. Multicentric experience, retrospective analysis of risk factors and review of the literature / R. Ruggiero, L. Sparavigna, G. Docimo [et al.] // Ann. Ital. Chir. - 2011. - N. 82 (5). - P. 369-375. 10. Spontaneous rupture of a sigmoid colon gastrointestinal stromal tumor manifesting as pneumoretroperitoneum with localized peritonitis: report of a case / Y. Hwangbo, J. Y. Jang, H. J. Kim [et al.] // Surg. Today. - 2011. - No. 41 (8). - P. 1085-1090.

11. Peritoneal cytokines as early markers of peritonitis following surgery for colorectal carcinoma: a prospective study / T. Yamamoto, S. Umegae, K. Matsumoto, A. R. Saniabadi // Cytokine. 2011. - No. 53 (2). - P. 239-242. 